\title{
Essential Oil of Phyllanthus reticulatus Poiret from Nigeria*
}

\author{
Akintayo L. Ogundajo', Afusat M. Aruna', Ayo 0. Owolabi', Isiaka A. Ogunwande"\#, \\ Guido Flamini² \\ ${ }^{1}$ Natural Products Research Unit, Department of Chemistry, Faculty of Science, Lagos State University, PMB \\ 0001, LASU Post Office, Ojo, Lagos, Nigeria \\ ${ }^{2}$ Dipartimento di Scienze Farmaceutiche, sede Chimica Bioorganica e Biofarmacia, Universita di Pisa, Via \\ Bonanno 33, Pisa, Italy \\ Email: "isiaka.ogunwande@lasu.edu.ng
}

Received 13 October 2014; revised 20 November 2014; accepted 21 December 2014

Copyright (C) 2015 by authors and Scientific Research Publishing Inc.

This work is licensed under the Creative Commons Attribution International License (CC BY).

http://creativecommons.org/licenses/by/4.0/

c) (i) Open Access

\section{Abstract}

The chemical composition of the essential oil obtained by hydrodistillation from the leaves of Phyllanthus reticulatus Poiret (Euphorbiaceae) growing in Nigeria has been studied. The constituents of the oil were analyzed by means of gas chromatography (GC-FID) and gas chromatography coupled with mass spectrometry (GC-MS). Monoterpenes (64.9\%) were the dominant class of compounds, followed by sesquiterpenes (23.0\%). The major constituents were $\alpha$-pinene $(6.0 \%)$, sabinene (7.6\%), $\beta$-pinene (18.1\%), linalool (6.9\%) and camphor $(7.7 \%)$, among the monoterpenes, and $\beta$-caryophyllene $(11.9 \%)$ and germacrene $D(8.6 \%)$ among the sesquiterpenes. This is the first report on the volatile constituents of Phyllanthus reticulatus.

\section{Keywords}

Phyllanthus reticulatus, Essential Oil Composition, Monoterpenes, Sesquiterpenes

\section{Introduction}

Phyllanthus reticulatus Poiret., (Family Euphorbiaceae) is a many branched deciduous shrub or small tree sometimes partially scrambling, usually $1-5 \mathrm{~m}$ high. $P$. reticulatus usually has a distinct smell that is emitted by the minute flowers when they open towards the early evening. The bark is light reddish-brown or grey-brown with

\footnotetext{
"Presented as Poster (BV-55) at the 44th International Symposium on Essential Oil (ISEO-44), Danubius Hotel, Flamenco, Budapest, Hungary, September 8-12, 2013.

"Corresponding author.

How to cite this paper: Ogundajo, A.L., Aruna, A.M., Owolabi, A.O., Ogunwande, I.A. and Flamini, G. (2015) Essential Oil of Phyllanthus reticulatus Poiret from Nigeria. American Journal of Plant Sciences, 6, 6-13.
} 
hairy stems when young, which become smooth with age. The leaves alternate along slender branches. They are up to $25 \mathrm{~cm}$ long and appear as leaflets of large pinnate leaves. The leaves are thinly textured, usually hairless. It flowers from September to October, but the flowering season can extend from July onwards. P. reticulatus has very small, roundish berry like fruits that are green at first, turning purple-black, 4 - $6 \mathrm{~mm}$ in diameter [1]. Extracts of the plant is known to possess both analgesic and anti-inflammatory activities [2]-[4]. Aqueous extract of $P$. reticulatus can be utilized for prevention of atherosclerosis in hypercholesterolemic patients [5]. There are reports which describe the antiviral [6], antibacterial [7], hepatoprotective 8], antioxidant [9], potential RNase $\mathrm{H}$ inhibition and protection against the viral cytopathic effects of HIV-1 [10], antidiabetic [11] and hypoglycemic [12] activities.

Some biologically active compound such as 2- $\alpha$-hydroxyfriedel-4(23)-en-3-one and other triterpenoids [13], purine, 3-(3-methylbut-2-en-1-yl)isoguanine and cleistanthane-type diterpenoid glucoside, 19-hydroxyspruceanol 19-O- $\beta$-D-glucopyranoside [14], (5R, 6R)-4,6-Dimethoxycarbonyl-5-[2',3',4'-trihydroxy-6'-(methoxycarbonyl) phenyl]-5,6-dihydro-2H-pyran-2-one, 3,4,3'-tri-O-methylellagic acid and methyl gallate [15], reticulatusides A and B [16], cytotoxic scopoletin [17] and flavonoid glycosides [18] [19] have been isolated from this plant. The isolation of lupeol, stigmasterol and lupeol acetate from the plant have been reported [20]. Regarding the volatile constituents, there appears to be no published work.

The objective of the present work was to examine the volatile constituents of this plant for future exploration. Our finding into the volatile oils of some poorly studied Nigerian flora was recently published [21].

\section{Materials and Methods}

\subsection{Plant Sample}

Leaves of P. reticulatus were collected from a location in Ibefun, Odogbolu, Ogun State, Nigeria, on March, 2012. Botanical identification was performed by Messrs Ugbogu O.A and Shasanya, O.S., at the Herbarium Headquarters, Forestry Research Institute of Nigeria (FRIN), Ibadan, Nigeria, where voucher specimen (FHI 109586) has been deposited for future reference.

\subsection{Extraction of Essential Oil}

Aliquots (400 g) of the air-dried and pulverized plant sample were subjected to hydrodistillation for $3 \mathrm{~h}$ using a Clevenger-type apparatus in accordance with the British Pharmacopoeia specification [22] to produce a pale yellow essential oil.

\subsection{Analysis of the Oil}

GC analysis was accomplished with a HP-5890 Series II instrument equipped with a HPWax and HP-5 capillary columns (both $30 \mathrm{~m} \times 0.25 \mathrm{~mm}, 0.25 \mu \mathrm{m}$ film thickness), working with the following temperature program: $60^{\circ} \mathrm{C}$ for $10 \mathrm{~min}$, rising at $5^{\circ} \mathrm{C} / \mathrm{min}$ to $220^{\circ} \mathrm{C}$. The injector and detector temperatures were maintained at $250^{\circ} \mathrm{C}$; carrier gas nitrogen $(2 \mathrm{~mL} / \mathrm{min})$; detector dual, FID; split ratio 1:30. The volume injected was $0.5 \mu \mathrm{L}$. The relative proportions of the oil constituents were percentages obtained by FID peak-area normalization without the use of response factor.

GC-EIMS analysis was performed with a Varian CP-3800 gas-chromatograph equipped with a HP-5 capillary column $(30 \mathrm{~m} \times 0.25 \mathrm{~mm}$; film thickness $0.25 \mu \mathrm{m})$ and a Varian Saturn 2000 ion trap mass detector. Analytical conditions: injector and transfer line temperature $220^{\circ} \mathrm{C}$ and $240^{\circ} \mathrm{C}$ respectively; oven temperature programmed from $60^{\circ} \mathrm{C}-240^{\circ} \mathrm{C}$ at $3^{\circ} \mathrm{C} / \mathrm{min}$; carrier gas was helium at a flow rate of $1 \mathrm{~mL} / \mathrm{min}$; injection of $0.2 \mu \mathrm{L}(10 \%$ hexane solution); split ratio 1:30. Mass spectra were recorded at $70 \mathrm{eV}$. The acquisition mass range was $30-300$ $\mathrm{m} / \mathrm{z}$ at a scan rate of $1 \mathrm{scan} / \mathrm{sec}$.

\subsection{Identification of the Constituents}

Identification of the constituents was based on comparison of the retention times with those of authentic samples, comparing their linear retention indices (LRI) relative to the series of n-hydrocarbons, and on computer matching against commercially available spectral [23]-[25]. Further identifications were also made possible by the use of homemade library mass spectra built up from pure substances and components of known oils and MS literature data. Moreover, the molecular weights of all the identified substances were confirmed by GC-CIMS, using 
$\mathrm{MeOH}$ as $\mathrm{CI}$ ionizing gas.

\section{Results and Discussion}

$P$. reticulatus yielded low content of essential oil $0.12 \%(\mathrm{v} / \mathrm{w})$ on a dry weight basis. Table 1 shows the identities of 84 compounds identified in the oil of $P$. reticulatus, accounting for $99.7 \%$ of the total oil contents. Figure 1 depicts the GC chromatogram of the essential oil. The classes of compounds identified in the oil were monoterpene hydrocarbons (42.0\%), oxygenated monoterpenoids (23.5\%), sesquiterpene hydrocarbons (29.4\%), oxygenated sesquiterpenoids (3.6\%) and non-terpene derivatives (1.2\%). The major oil constituents were $\alpha$-pinene (6.0\%), sabinene (7.6\%), $\beta$-pinene (18.1\%), linalool (6.9\%) and camphor (7.7\%), among the monoterpenes; and $\beta$-caryophyllene (11.9\%) and germacrene $\mathrm{D}(8.6 \%)$ among the sesquiterpenes. This may represent the first analysis of the oil of this species.

Regardless of Phyllanthus being large family, with about 1000 species, the essential oils of $P$. reticulatus has not been investigated. However, the volatile constituents of few species grown have been reported. Phytol (21.5\%), $\beta$-citronellol (17.7\%), trans-geraniol (13.5\%), cis-3-hexenol (12.6\%) and 1-hexanol (11.3\%) were the major constituents of Phyllanthus salviaefolius H.B.K. [26]. However, linalool (36.4\%) and phytol (13.0\%) dominated the oil of Phyllanthus amarus Sch. and Thonn [27]. Volatile compounds have been isolated from $P$. acidus (L.) Skeels fruits fermented for 1, 3 and 6 months. Among the 46 compounds identified, acids and alcohols dominated the volatiles profile; acids particularly characterized the quantitative profile of the volatile compounds after 6 months of fermentation. Other significant changes were in the sesquiterpenes, with increments of $\delta$-and $\alpha$-cadinene after 3 months of fermentation, and $\alpha$-cadinol and $\tau$-muurolol after 6 months [28]. Phyllanthus arenarius Beille in Lecomte has $n$-hexadecanoic acid (14.0\%), 1,2-benzene dicarboxylic acid, bis (2-methylpropyl) ester $(12.7 \%)$ and di-n-octyl phthalate $(10.3 \%)$ as its main compounds [29] while Phyllanthus urinata L., was rich in 3,3,5-trimethylcyclohexanone (17.2\%) and $n$-hexadecanoic acid (12.4\%). The abundant of 3,3,5-trimethylcyclohexanone (12.4\%) and 3,7-dimethyl-1,6-octadien-3-ol (10.2\%) was reported in the oil of Phyllanthus niriru L. [29]. The essential oil of Phyllanthus emblica L. contained high amounts of $\beta$-caryophyllene, $\beta$-bourbonene, 1-octen-3-ol, thymol, and methyleugenol [30]. Another investigation reported that $\beta$-bourbonene, heptadecanol, pentadecanone, thymol, $\beta$-caryophyllene, $\beta$-neoclovene, nerol and borneol were the major compounds were the main oil contents of the plant [31]. (E)-Isoelemicin (36.40\%) was the main compounds of Phyllanthus muellerianus (Kuntze) Excel which also showed antimicrobial property [32].

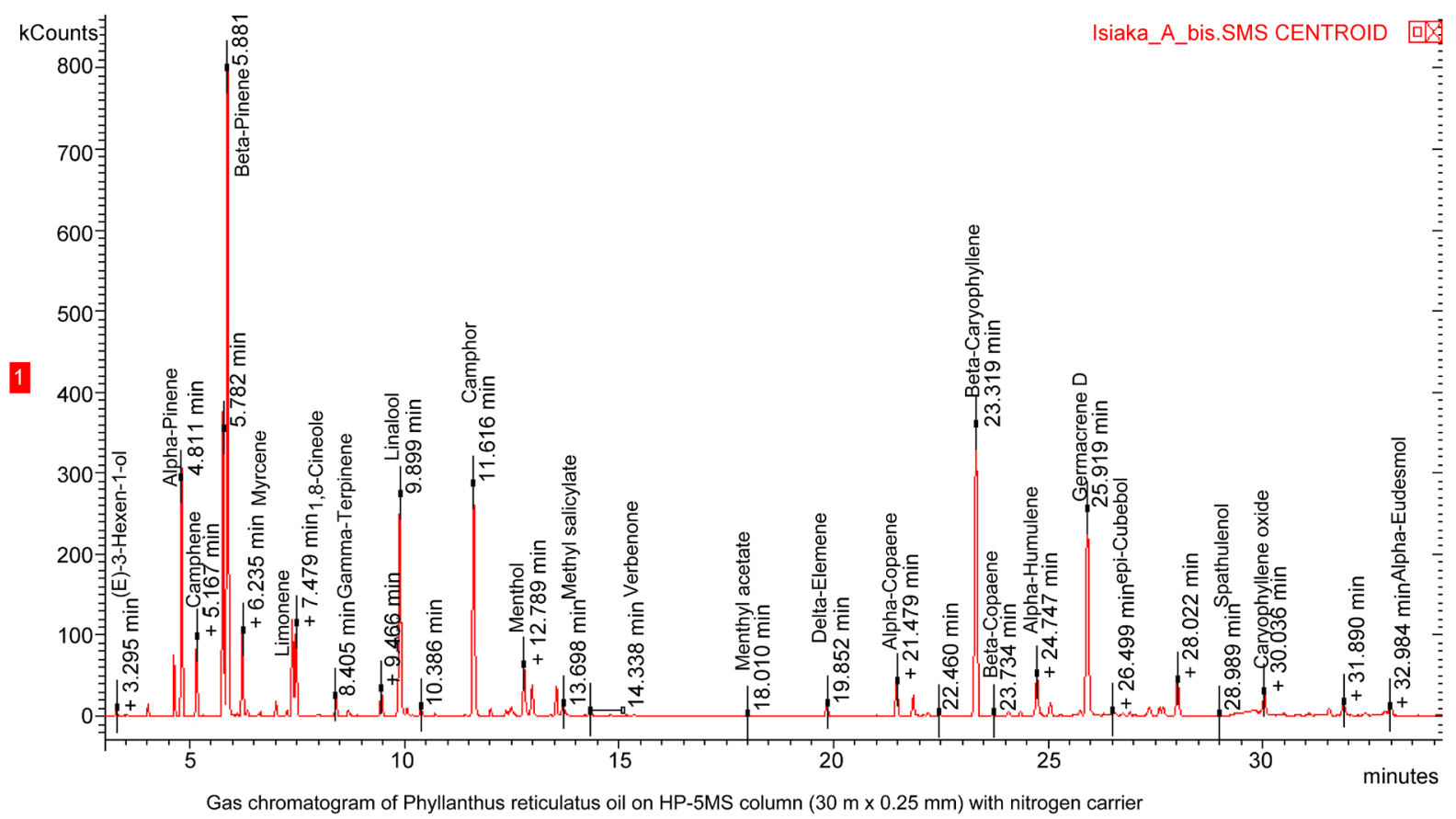

Figure 1. Gas chromatogram of Phyllanthus reticulates oil on HP-5MS column (30 m $\times 0.25 \mathrm{~mm})$ with nitrogen carrier. 
A. L. Ogundajo et al.

Table 1. Essential oil constituents of Phyllanthus reticulates.

\begin{tabular}{|c|c|c|c|c|}
\hline Compounds $^{a}$ & Retention Times ${ }^{\mathrm{b}}$ & $\mathrm{RI}^{\mathrm{c}}$ & $\mathrm{RI}^{\mathrm{d}}$ & Percentage (\%) \\
\hline (E)-Hex-3-en-1-ol & 3.29 & 854 & 850 & 0.4 \\
\hline Hexan-1-ol & 3.48 & 872 & 863 & $\operatorname{Tr}$ \\
\hline$n$-Nonane & 4.02 & 900 & 900 & 0.3 \\
\hline Tricyclene & 4.55 & 928 & 921 & $\operatorname{Tr}$ \\
\hline$\alpha$-Thujene & 4.64 & 931 & 924 & 1.3 \\
\hline $\boldsymbol{\alpha}$-Pinene & 4.81 & 940 & 932 & 6.0 \\
\hline Camphene & 5.16 & 954 & 946 & 1.9 \\
\hline Thuja-2,4(10)-diene & 5.29 & 958 & 953 & $\operatorname{Tr}$ \\
\hline Benzaldehyede & 5.45 & 962 & 962 & $\operatorname{Tr}$ \\
\hline Sabinene & 5.78 & 977 & 969 & 7.6 \\
\hline $\boldsymbol{\beta}$-Pinene & 5.88 & 980 & 974 & 18.1 \\
\hline Octan-3-one & 6.11 & 988 & 979 & $\operatorname{Tr}$ \\
\hline Myrcene & 6.23 & 992 & 988 & 2.4 \\
\hline Octan-3-ol & 6.34 & 995 & 988 & $\operatorname{Tr}$ \\
\hline$\alpha$-Phellandrene & 6.64 & 1005 & 1002 & $\operatorname{Tr}$ \\
\hline$\alpha$-Terpinenne & 7.01 & 1018 & 1014 & 0.4 \\
\hline p-Cymene & 7.26 & 1027 & 1020 & 0.2 \\
\hline Limonene & 7.39 & 1031 & 1024 & 2.6 \\
\hline 1,8-Cineole & 7.48 & 1034 & 1026 & 2.7 \\
\hline (Z)- $\boldsymbol{\beta}$-Ocimene & 7.69 & 1041 & 1032 & $\operatorname{Tr}$ \\
\hline (Z)-Oct-3-en-1-ol & 7.97 & 1047 & 1047 & $\operatorname{Tr}$ \\
\hline (E)- $\boldsymbol{\beta}$-Ocimene & 8.04 & 1051 & 1044 & $\operatorname{Tr}$ \\
\hline $\boldsymbol{\gamma}$-Terpinene & 8.41 & 1062 & 1054 & 0.6 \\
\hline cis-Sabinene hydrate & 8.70 & 1070 & 1065 & 0.2 \\
\hline cis-Linalool oxide (furanoid) & 8.89 & 1075 & 1067 & $\operatorname{Tr}$ \\
\hline Non-1-en-3-ol & 9.16 & 1083 & 1088 & $\operatorname{Tr}$ \\
\hline Terpinolene & 9.47 & 1089 & 1086 & 0.9 \\
\hline Linalool & 9.90 & 1099 & 1095 & 6.9 \\
\hline$n$-Nonanal & 10.07 & 1103 & 1100 & 0.2 \\
\hline Octen-1-ol acetate & 10.39 & 1107 & 1110 & 0.3 \\
\hline cis-p-Menth-2-en-1-ol & 10.72 & 1122 & 1118 & $\operatorname{Tr}$ \\
\hline trans-p-Menth-2-en-1-ol & 11.43 & 1125 & 1136 & $\operatorname{Tr}$ \\
\hline Camphor & 11.62 & 1144 & 1141 & 7.7 \\
\hline Menthone & 12.01 & 1155 & 1158 & 0.3 \\
\hline Pinocarvone & 12.37 & 1163 & 1160 & 0.2 \\
\hline
\end{tabular}




\section{Continued}

\begin{tabular}{|c|c|c|c|c|}
\hline Borneol & 12.49 & 1166 & 1165 & 0.5 \\
\hline Menthol & 12.79 & 1174 & 1167 & 1.9 \\
\hline Terpinen-4-ol & 12.97 & 1178 & 1174 & 1.1 \\
\hline (Z)-Hex-3-enyl butanoate & 13.41 & 1186 & 1184 & $\operatorname{Tr}$ \\
\hline $\boldsymbol{\alpha}$-Terpineol & 13.54 & 1190 & 1186 & 1.0 \\
\hline Methyl salicylate & 13.70 & 1192 & 1190 & 0.6 \\
\hline$n$-Decanal & 14.21 & 1205 & 12.01 & $\operatorname{Tr}$ \\
\hline Verbenone & 14.34 & 1208 & 1204 & 0.3 \\
\hline $\boldsymbol{\beta}$-Cyclocitral & 14.80 & 1218 & 1217 & $\operatorname{Tr}$ \\
\hline Nerol & 15.18 & 1228 & 1227 & $\operatorname{Tr}$ \\
\hline 3-Methyl-hex-3-en-1-yl butanoate & 15.36 & 1236 & 1232 & $\operatorname{Tr}$ \\
\hline Piperitone & 16.24 & 1253 & 1249 & $\operatorname{Tr}$ \\
\hline Menthyl acetate & 18.01 & 1294 & 1294 & 0.1 \\
\hline$\delta$-Elemene & 19.85 & 1340 & 1335 & 0.5 \\
\hline $\boldsymbol{a}$-Cubebene & 20.36 & 1351 & 1345 & $\operatorname{Tr}$ \\
\hline Eugenol & 20.74 & 1358 & 1356 & $\operatorname{Tr}$ \\
\hline $\boldsymbol{\alpha}$-Copaene & 21.48 & 1376 & 1374 & 1.5 \\
\hline $\boldsymbol{\beta}$-Bourbonene & 21.58 & 1384 & 1387 & 1.0 \\
\hline $\boldsymbol{\beta}$-Cubebene & 22.11 & 1390 & 1387 & $\operatorname{Tr}$ \\
\hline $\boldsymbol{\beta}$-Elemene & 22.28 & 1392 & 1389 & 0.2 \\
\hline Cyperene & 22.46 & 1398 & 1398 & 0.2 \\
\hline Isocaryophyllene & 22.79 & 1405 & 1408 & $\operatorname{Tr}$ \\
\hline Dodecanal & 22.97 & 1408 & 1408 & $\operatorname{Tr}$ \\
\hline $\boldsymbol{\beta}$-Caryophyllene & 23.32 & 1418 & 1417 & 11.9 \\
\hline $\boldsymbol{\beta}$-Copaene & 23.73 & 1429 & 1430 & 0.2 \\
\hline$\alpha$-Guaiene & 24.08 & 1439 & 1437 & 0.2 \\
\hline Aromadendrene & 24.35 & 1441 & 1439 & 0.2 \\
\hline$\alpha$-Humulene & 24.75 & 1455 & 1452 & 1.8 \\
\hline allo-Aromadendrene & 25.05 & 1461 & 1458 & 0.5 \\
\hline cis-Muurola-4(14),5-diene & 25.29 & 1463 & 1465 & $\operatorname{Tr}$ \\
\hline$\gamma$-Muurolene & 25.74 & 1477 & 1479 & 1.8 \\
\hline Germacrene D & 25.92 & 1480 & 1484 & 8.6 \\
\hline$(E)$ - $\boldsymbol{\beta}$-Ionone & 26.18 & 1485 & 1487 & $\operatorname{Tr}$ \\
\hline cis- $\boldsymbol{\beta}$-Guaiene & 26.31 & 1490 & 1492 & $\operatorname{Tr}$ \\
\hline epi-Cubebol & 26.50 & 1494 & 1493 & 0.4 \\
\hline
\end{tabular}




\section{Continued}

\begin{tabular}{|c|c|c|c|c|}
\hline trans- $\boldsymbol{\beta}$-Guaiene & 26.75 & 1500 & 1502 & $\operatorname{Tr}$ \\
\hline $\boldsymbol{\alpha}$-Bulnesene & 26.90 & 1505 & 1509 & 0.3 \\
\hline$\delta$-Amorphene & 27.02 & 1512 & 1511 & $\operatorname{Tr}$ \\
\hline Cubebol & 27.35 & 1515 & 1514 & 0.5 \\
\hline $\boldsymbol{\delta}$-Cadinene & 27.69 & 1524 & 1522 & 0.4 \\
\hline Germacrene B & 28.83 & 1556 & 1559 & 0.1 \\
\hline Spathulenol & 28.99 & 1576 & 1577 & 0.4 \\
\hline Caryophyllene oxide & 30.04 & 1581 & 1582 & 1.2 \\
\hline Humulene epoxide II & 31.07 & 1606 & 1608 & $\operatorname{Tr}$ \\
\hline 1,10-di-epi-Cubenol & 31.54 & 1614 & 1618 & 0.3 \\
\hline$\tau$-cadinol & 32.39 & 1641 & 1639 & 0.2 \\
\hline Cubenol & 32.56 & 1647 & 1645 & $\operatorname{Tr}$ \\
\hline $\boldsymbol{\alpha}$-Cadinol & 32.86 & 1652 & 1652 & 0.2 \\
\hline$\alpha$-Eudesmol & 32.98 & 1654 & 1652 & 0.4 \\
\hline \multicolumn{4}{|c|}{ TOTAL } & 99.7 \\
\hline \multicolumn{4}{|c|}{ Monoterpene hydrocarbons } & 42.0 \\
\hline & \multicolumn{3}{|c|}{ Oxygenated monoterpenes } & 23.5 \\
\hline & \multicolumn{3}{|c|}{ Sesquiterpene hydrocarbons } & 29.4 \\
\hline & \multicolumn{3}{|c|}{ Oxygenated sesquiterpenes } & 3.6 \\
\hline & \multicolumn{3}{|c|}{ Others } & 1.2 \\
\hline
\end{tabular}

${ }^{a}$ Elution order on HP-5MS column; ${ }^{b}$ Retention time in order with respect to the chromatogram (Figure 1); ${ }^{~}$ Retention indices on HP-5 MS capillary column; ${ }^{\mathrm{d}}$ Literature retention indices (References 23 - 25); Tr, Trace amounts $<0.1 \%$.

The main compounds of $P$. salviaefolius could not be identified in $P$. reticulatus. Except for linalool, the quantitatively significant compounds of $P$. amarus were conspicuously absent from $P$. reticulatus. Also, the low contents of $\delta$-cadinene and $\alpha$-cadinol, and the absence of the sesquiterpenoid compounds such as $\alpha$-cadinene and $\tau$-muurolol in this study makes the composition differ from that found in P. acidus. Also, the major compounds in the oils of $P$. arenarius, $P$. urinate and $P$. niriru were absent in $P$. reticulatus. In addition, the oil of $P$. reticulatus could be distinguished from those of $P$. embelica by its lack of thymol, methyleugenol, heptadecanol, pentadecanone and nerol. Notably, $(E)$-isoelemicin, the main compound of $P$. muellerianus was not identified in $P$. reticulatus.

\section{Conclusion}

The chemical constituents of essential oil obtained from P. reticulatus grown in Nigeria are being reported for the first time. In addition, a comparison of the chemical composition was made with the other known essential oils from Phyllanthus plants. It could be seen that the essential oils of Phyllanthus plants exhibit high chemical variability. Each species has its own compositional pattern different from other. The very high content of compounds identified in the oil of $P$. reticulatus may be an important chemical and economic characteristic of the oil sample.

\section{Acknowledgements}

Authors are grateful to Messrs Ugbogu and Shasanya for the botanical identification of the plant. 


\section{References}

[1] Palgrave, M.C. (2002) Trees of Southern Africa. Third Edition, Struik Publisher, Cape Town.

[2] Saha, A., Masud, M.A., Bachar, S.C., Kundu, J.K., Nahar, L., Datta, B.K. and Sarker, S.D. (2007) The Analgesic and Anti-inflammatory Activities of The Extracts of Phyllanthus reticulatus in Mice Model. Pharmaceutical Biology, 45, 355-359. http://dx.doi.org/10.1080/13880200701212973

[3] Sunil, K., Shalini, S., Dinesh, K., Tarun, K., Renu, A. and Karunesh, A. (2012) Pharmacognostic Study and Anti-inflammatory Activity of Phyllanthus reticulatus Poir. Fruit. Asian Pacific Journal of Tropical Disease, 2, S332-S335. http://dx.doi.org/10.1016/S2222-1808(12)60177-7

[4] Patel, J. and Gaudani, K. (2011) Evaluation of Anti-Inflammatory Activity of Petroleum Ether and Methanolic Extract of Phyllanthus reticulatus Leaves. Journal of Advanced Pharmacy Education and Research, 1, 266-270.

[5] Maruthappan, V. and Shree, K.S. (2010) Effects of Phyllanthus reticulatus on Lipid Profile and Oxidative Stress in Hypercholesterolemic Albino Rats. Indian Journal of Pharmacology, 42, 388-391. http://dx.doi.org/10.4103/0253-7613.71923

[6] Das, B.K., Shohel, M., Pavel, A.M., Akhter, N., Yasmin, T., Bhattacherjee, R., Das, B. and Hannan, J.M.A. (2011) Anti-Hepatitis B Viral Activity of Phyllanthus reticulatus. Bangladesh Pharmaceutical Journal, 14, 11-14.

[7] Akhtar, M.A., Sharmin, S.A., Rahman, M.A., Rahman, M.M., Khalekuzzaman, M.K., Anisuzzaman, M. and Alam, M.F. (2013) Antibacterial Potential of Leaf Extracts from Phyllanthus reticulatus. International Journal of Pharmacy and Research Development, 5, 85-95.

[8] Das, B.K., Bepary, S., Datta, B.K., Choudahry, A.K.A., Ali, M.S. and Rouf, A.S.S. (2008) Hepatoprotective Activity of Phyllanthus reticulatus. Pakistan Journal of Pharmaceutical Science, 21, 333-337.

[9] Sani, M.F., Kouhsari, S.M. and Moradabadi, L. (2012) Effects of Three Medicinal Plants Extracts in Experimental Diabetes: Antioxidant Enzymes Activities and Plasma Lipids Profiles in Comparison with Metformin. Iranian Journal of Pharmaceutical Research, 1, 897-903.

[10] Tai, B.H., Nhut, N.D., Nhiem, N.X., Quang, T.H., Thanh, N.T.N., Luyen, B.T.T., Huong, T.T., Wilson, J., Beutler, J.A., Ban, N.K., Cuong, N.M. and Kim, Y.H. (2011) An Evaluation of the RNase H Inhibitory Effects of Vietnamese Medicinal Plant Extracts and Natural Compounds. Pharmaceutical Biology, 49, 1046-1051. http://dx.doi.org/10.3109/13880209.2011.563316

[11] Kumar, S., Kumar, D., Deshmukh, R.R., Lokhande, P.D., More, S.N. and Rangari, V.D. (2008) Antidiabetic Potential of Phyllanthus reticulatus in Alloxan-Induced Diabetic Mice. Fitoterapia, 79, 21-23. http://dx.doi.org/10.1016/j.fitote.2007.06.012

[12] Kumar, S., Kumar, D., Deshmukh, R.R. and Rangari, V.D. (2007) Hypoglycemic Activity of Roots of Phyllanthus reticulatus in Alloxan Induced Diabetic Mice. International Journal of Plant Science, 2, 184-187.

[13] Hui, W.H., Li, M.M. and Wong, K.M. (1976) A New Compound, 21 $\alpha$-Hydroxyfriedel-4(23)-en-3-One and Other Triterpenoids from Phyllanthus reticulatus. Phytochemistry, 15, 797-798. http://dx.doi.org/10.1016/S0031-9422(00)94448-0

[14] Lan, M.S., Ma, J.X., Tan, C.H., Wei, S. and Zhu, D.Y. (2010) Chemical Constituents of Phyllanthus reticulatus. Helvetica Chimica Acta, 93, 2276-2280. http://dx.doi.org/10.1002/hlca.201000168

[15] Pojchaijongdee, N., Sotanaphun, U., Limsirichaikul, S. and Poobrasert, O. (2010) Geraniinic Acid Derivative from the Leaves of Phyllanthus reticulatus. Pharmaceutical Biology, 48, 740-744. http://dx.doi.org/10.3109/13880200903273898

[16] Ma, J.X., Lan, M.S., Qu, S.J., Tan, J.J., Luo, H.F., Tan, C.H. and Zhu, D.Y. (2012) Arylnaphthalene Lignan Glycosides and Other Constituents from Phyllanthus reticulatus. Journal of Asian Natural Products Research, 14, 1073-1077. http://dx.doi.org/10.1080/10286020.2012.712040

[17] Begum, T., Rahman, M.S. and Rashid, M.A. (2006) Phytochemical and Biological Investigations of Phyllanthus reticulatus. Dhaka University Journal of Pharmaceutical Sciences, 5, 21-23.

[18] Lam, S.H., Wang, C.Y., Chen, C.K. and Lee, S.S. (2007) Chemical Investigation of Phyllanthus reticulatus by HPLC-SPE-NMR and Conventional Methods. Phytochemical Analysis, 18, 251-255. http://dx.doi.org/10.1002/pca.979

[19] Sharma, S. and Kumar, S. (2013) Phyllanthus reticulatus Poir.-An Important Medicinal Plant: A Review of Its Phytochemistry, Traditional Uses and Pharmacological Properties. International Journal of Pharmaceutical Sciences \& Research, 4, 2528-2534.

[20] Jamal, A.K., Yaacob, W.A. and Din, L.B. (2008) A Chemical Study on Phyllanthus reticulatus. Journal of Physical Science, 19, 45-50.

[21] Ogundajo, A.L., Ogunwande, I.A., Bolarinwa, T.M., Joseph, O.R. and Flamini, G. (2014) Essential Oil from the 
Leaves of Hibiscisus suranthesis L. from Nigeria. Journal of Essential Oil Research, 26, 114-117. http://dx.doi.org/10.1080/10412905.2013.860410

[22] British Pharmacopoeia (1980) Vol II, H.M. Stationary Office.

[23] Adams, R.P. (2007) Identification of Essential Oil Components by Gas Chromatography/Quadrupole Mass Spectrometry. 4th Edition, Allured Publishing Corporation, Carol Stream.

[24] Joulain, D. and Koenig, W.A. (1989) The Atlas of Spectral Data of Sesquiterpene Hydrocarbons. E.B. Verlag, Hamburg.

[25] National Institute of Standards and Technology (2011) Chemistry Web Book. Data from NIST Standard Reference Database 69. http://www.nist.gov/

[26] Villarreal, S., Bojas, L.B., Usubillaga, A., Ramirez, I. and Solorzano, M. (2008) Volatile Constituents from the Leaves of Phyllantus salviaefolius H.B.K. from the Venezuelan Andes. Natural Product Communications, 3, 275-277.

[27] Moronkola, D.O., Ogunwande, I.A., Oyewole, I.O., Başer, K.H.C., Ozek, T. and Ozek, G. (2009) Studies on the Volatile Oils of Momordica charantia L. (Cucurbitaceae) and Phyllanthus amarus Sch. \& Thonn. (Euphorbiaceae). Journal of Essential Oil Research, 21, 393-399. http://dx.doi.org/10.1080/10412905.2009.9700201

[28] Quijano, C.E., Linares, D. and Pino, J.A. (2007) Changes in Volatile Compounds of Fermented Cereza Agria [Phyllanthus acidus (L.) Skeels] Fruit. Flavour and Fragrance Journal, 22, 392-394. http://dx.doi.org/10.1002/ffj.1810

[29] Li, X., Wei, W.X. and Lin, C.W. (2008) Comparative Analysis of Essential Oil Compositions from Phyllanthus niriru, $P$. urinaria, and P. arenarius. Chemistry of Natural Compounds, 44, 257-259.

[30] Liu, X.L., Zhao, M.M., Luo, W., Yang, B. and Jiang, Y.M. (2009) Identification of Volatile Components in Phyllanthus emblica L. and Their Antimicrobial Activity. Journal of Medicinal Food, 12, 423-428. http://dx.doi.org/10.1089/jmf.2007.0679

[31] Liu, X.L., Zhao, M.M., Wang, J.S. and Wei, L. (2008) Effectiveness of Phyllanthus emblica L. Essential Oil to Inhibit the Growth of Food-Spoiling Yeasts. Journal of Food Safety, 28, 261-275. http://dx.doi.org/10.1111/j.1745-4565.2008.00119.x

[32] Brusotti, G., Cesari, I., Gilardoni, G., Tosi, S., Grisoli, P., Picco, A.M. and Caccialanza, G. (2012) Chemical Composition and Antimicrobial Activity of Phyllanthus muellerianus (Kuntze) Excel Essential Oil. Journal of Ethnopharmacology, 142, 657-662. http://dx.doi.org/10.1016/j.jep.2012.05.032 
Scientific Research Publishing (SCIRP) is one of the largest Open Access journal publishers. It is currently publishing more than 200 open access, online, peer-reviewed journals covering a wide range of academic disciplines. SCIRP serves the worldwide academic communities and contributes to the progress and application of science with its publication.

Other selected journals from SCIRP are listed as below. Submit your manuscript to us via either submit@scirp.org or Online Submission Portal.
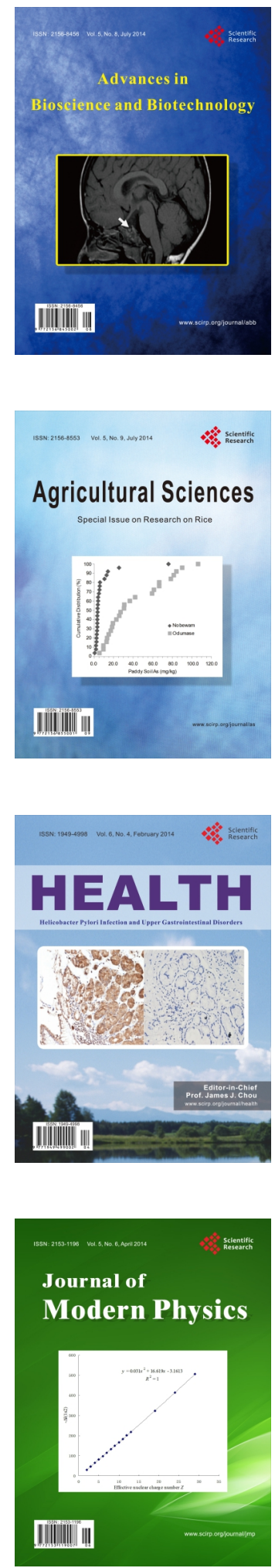
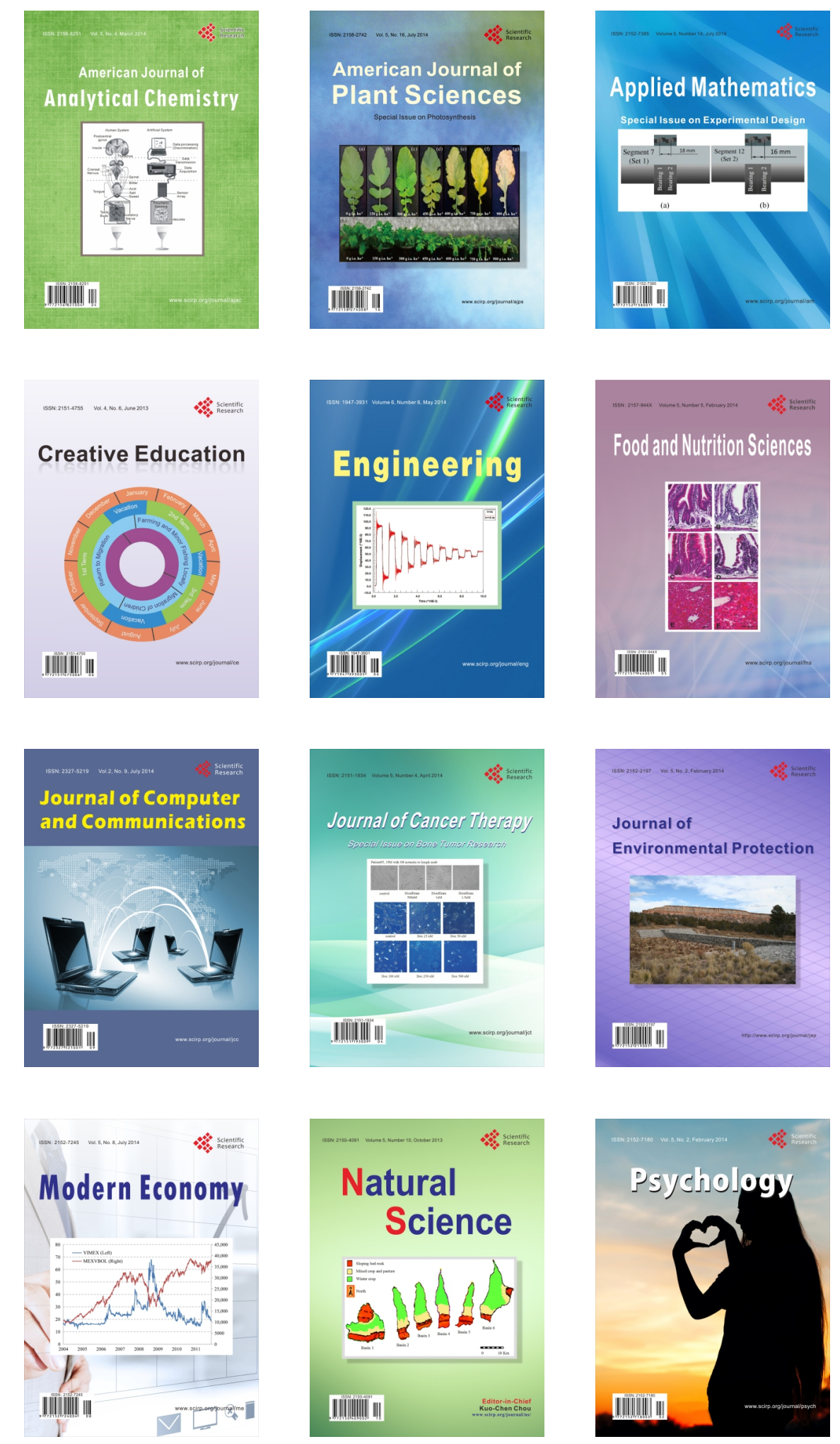